\title{
Educational and occupational aspirations at the end of secondary school: The importance of regional labour- market conditions
}

Citation for published version (APA):

Hartung, A., Wessling, K., \& Hillmert, S. (2019). Educational and occupational aspirations at the end of secondary school: The importance of regional labour-market conditions. Maastricht University, Graduate School of Business and Economics. GSBE Research Memoranda No. 019 https://doi.org/10.26481/umagsb.2019019

Document status and date:

Published: 02/07/2019

DOI:

10.26481/umagsb.2019019

Document Version:

Publisher's PDF, also known as Version of record

Please check the document version of this publication:

- A submitted manuscript is the version of the article upon submission and before peer-review. There can be important differences between the submitted version and the official published version of record.

People interested in the research are advised to contact the author for the final version of the publication, or visit the DOI to the publisher's website.

- The final author version and the galley proof are versions of the publication after peer review.

- The final published version features the final layout of the paper including the volume, issue and page numbers.

Link to publication

\footnotetext{
General rights rights.

- You may freely distribute the URL identifying the publication in the public portal. please follow below link for the End User Agreement:

www.umlib.nl/taverne-license

Take down policy

If you believe that this document breaches copyright please contact us at:

repository@maastrichtuniversity.nl

providing details and we will investigate your claim.
}

Copyright and moral rights for the publications made accessible in the public portal are retained by the authors and/or other copyright owners and it is a condition of accessing publications that users recognise and abide by the legal requirements associated with these

- Users may download and print one copy of any publication from the public portal for the purpose of private study or research.

- You may not further distribute the material or use it for any profit-making activity or commercial gain

If the publication is distributed under the terms of Article 25fa of the Dutch Copyright Act, indicated by the "Taverne" license above, 


\title{
Educational and occupational aspirations at the end of secondary school: The importance of regional labour-market conditions
}

Andreas Hartung ${ }^{\text {a }}$, Katarina Weßling ${ }^{\mathrm{b}}$, Steffen Hillmert ${ }^{\mathrm{a}}$

\author{
${ }^{a}$ Department of Sociology, University of Tübingen, Wilhelmstr. 36, 72074 Tübingen, \\ Germany \\ ${ }^{b}$ Research Centre for Education and the Labour Market (ROA), Maastricht University \\ School of Business and Economics, P.O. Box 616, 6200 MD Maastricht, Netherlands \\ ${ }^{c}$ Institute for Housing and Environment, Rheinstr. 65, 64295 Darmstadt, Germany
}

\begin{abstract}
The transition from general schooling to vocational training or to the labour market marks a crucial threshold in the life course of young adults. It has been well documented that successful school-to-work transitions are influenced by (regional) labour-market conditions. However, what has been rather neglected is that before actual transitions take place, adolescents need to make plans and evaluate their wishes and choices against the background of existing constraints. (Regional) labour-market conditions are a part of such constraints. This paper complements previous research by focusing on the impact of the regional labour market on students' educational and occupational aspirations before school-to-work transitions take place. Regionalised administrative data on unemployment is linked with survey data from the Starting Cohort 4 of the German National Educational Panel Study (NEPS-SC4). Results indicate that a relatively higher level of regional unemployment is associated with aspirations for higher-status occupations. Their status aspiration push students towards continuing general school to obtain higher general qualifications. The effects vary with the attended secondary school track and with parents' educational aspirations for their children.
\end{abstract}




\section{Acknowledgement:}

We would like to thank Lynn van Vugt and Christoph Meng for their valuable comments on our manuscript. Also, we would like to thank the participants of the SPP1646 (DFG priority program) meetings for their comments on the paper. Research for this paper was supported by the German Research Foundation (DFG), Grants HI 767/7-1 and HI 767/72 and the Fritz Thyssen Foundation.

JEL classification: I24, R23, R12, D84

Keywords: educational and occupational aspirations/expectations, regional labourmarket conditions, school-to-work transitions 


\section{Introduction}

When the end of general schooling approaches, adolescents are faced with the question of which educational or occupational pathway to choose. This decision between alternatives such as vocational education and training (VET), further general education, or a direct labour-market entry entails a highly consequential transition in the individual life course. Educational and occupational aspirations form the basis of this decision. They have been shown to play a significant role for final educational and occupational outcomes (Schoon et al., 2007; Beal and Crockett, 2010; Gutman and Schoon, 2017; Holtmann et al., 2017).

School-to-work transitions are known to be influenced by various individual and structural characteristics including regional labour-market conditions. However, in previous research that concentrated on the relevance of regional conditions, the focus has most often been on fulfilled transitions to VET or to the labour market (e.g. Betts and McFarland, 1995; Rice, 1999; Clark, 2011; Meschi et al., 2011). We aim to further disentangle the link between regional conditions and school-to-work transitions by assessing the importance of regional labour-market conditions for educational and occupational aspirations of secondary-school students shortly before actual transitions take place.

In doing so, we propose an approach that integrates general educational aspirations with structural aspects of occupational aspirations. We empirically analyse to what extent regional labour-market conditions affect these different dimensions of aspirations. We distinguish between (1) security-related occupational aspirations, (2) status-related occupational aspirations and (3) educational aspirations for general schooling. Security-related occupational aspirations refer to the specific unemployment risk in the occupation that is aspired by the students. Status-related occupational aspirations refer to the levels of income and qualification in an aspired occupation. We argue that differentiating certain aspects of aspirations and capturing them simultaneously provides an in-depth understanding of the overall concept of aspirations and stresses the relevance of aspirations at specific stages in the individual life course.

In the subsequent section, we present the current state of research that links regional characteristics with educational outcomes as well as research on educational and occupational aspirations. Thereafter, we present our theoretical model; we link the 
Wisconsin model of status attainment with the rational-choice model of educational decision-making. Both approaches are frequently considered when focusing on educational aspirations. In section 4, we present our conceptual approach that links distinct dimensions of aspirations. In section 5, our hypotheses are presented. Subsequently, we discuss the applied data and empirical strategy to test the hypotheses empirically. Results indicate that a higher level of regional unemployment is associated with aspirations for higher-status occupations but not so much with aspirations for more secure occupations. The aspirations for higher-status occupations correspond with the aspirations to extend the general school career in order to obtain higher general qualifications. In the last section, we discuss our findings against the background of previous research and their relevance for research and policy makers.

\section{Previous research}

Previous studies have consistently shown that parents, peers, and the school (class) context matter in terms of both occupational and educational aspirations (Spera et al., 2009; Minello and Barban, 2012; Chesters and Smith, 2015). Regarding the importance of the residential environment, especially neighbourhood conditions have been considered in previous research on aspirations. Frostick et al. (2016) demonstrate for the case of London that high local deprivation can increase adolescents' educational aspirations, in particular for specific social groups (females and black students). In contrast, it could have been shown that favourable socio-structural neighbourhood conditions in Germany increase both occupational and educational aspirations (Wicht and Ludwig-Mayerhofer, 2014; Hartung and Hillmert, 2019).

Research that links regional characteristics with educational outcomes has frequently argued in favour of a positive relationship between poor socio-economic contexts and increased educational participation. Poor labour-market conditions in the region are expected to lower the individual perception of employment chances and therefore discourage young adults from entering employment after the end of compulsory schooling. They are rather encouraged to prolong their educational career and, hence, their overall educational attainment increases (discouraged worker effect; Raffe and Willms, 1989). In the US context it could be shown that further general education is used 
as an 'escape' from unemployment (Walters, 1984; Betts and McFarland, 1995). Similar results have been found in the UK (Rice, 1999; Clark, 2011), Italy (Carmeci and Chies, 2002), and Spain (Peraita and Pastor, 2000). In the case of Germany, differences between federal states and between regions reveal that unfavourable regional conditions (i.e. high unemployment) decrease individuals' chances to enter vocational training (Kleinert and Jacob, 2012). In addition, it could be shown that low-educated graduates are particularly vulnerable to structural labour-market conditions (Gesthuizen and Scheepers, 2010).

However, these empirical studies have concentrated on outcomes of fulfilled educational or occupational transitions, whereas educational aspirations of adolescents have been considered less frequently. Few research examples that integrate aspects of regions with aspirations as an outcome have focused on the distinction between rural and urban areas. These studies show that young adults in rural areas have lower occupational aspirations (Listhaug et al., 1982; Anders et al., 1999). Even though the results point to relations between substantive characteristics of regions and aspirations, the studies do not answer the question on how young adults integrate labour-market conditions in their immediate educational planning. We aim to address this gap in research in the this paper.

\section{The Wisconsin model of status attainment and the rational- choice model of educational decisions}

Aspirations can be defined as 'cognitive orientational aspect(s) of goal-directed behavior' (Haller, 1968). Theoretical debates have repeatedly addressed aspirations and the factors that influence them from both sociological and psychological perspectives; we make use of two major theoretical approaches that provide the possibility to emphasise structural aspects of aspirations and their relevance at a specific stage in the educational career. On the one hand, we argue from the perspective of the Wisconsin model of educational and occupational status attainment (e.g. Sewell et al., 1969); on the other hand, we make use of the rational-choice model of educational decisions (e.g. Boudon, 1974; Erikson and Jonsson, 1996; Breen and Goldthorpe, 1997). Central arguments of the two concepts complement each other fruitfully in establishing educational and occupational aspirations as relevant determinants of inequality while integrating contextual explanatory factors (following Morgan, 1998). 
The socio-psychological perspective of the Wisconsin model stresses the importance of socialisation in the formation of attitudes towards education and occupation; according to the model, aspirations are relevant for the prospective educational and occupational status, and they mediate the effect of social background. Individual aspirations are integrated into a path model and linked, on the one hand, to psychological explanatory factors such as cognitive ability and, on the other hand, to the social context of individuals (Sewell et al., 1969). Both educational and occupational aspirations are shaped by so-called significant others. Significant others represent a specific group of people, who play a prominent role in the every-day life of an individual (e.g. parents and peers). Their influence mediates the effects of individuals' socioeconomic status, cognitive ability, and performance on aspirations. Individuals obtain their level of aspiration via these significant others because they serve as role models or because individuals are confronted with particular expectations concerning their educational and occupational behaviour (Haller, 1982).

We integrate the idea of the Wisconsin model into the rational-choice model of educational decision-making, which has been frequently applied when focusing on trajectories and transitions across the educational life course (e.g. Erikson and Jonsson, 1996; Breen and Goldthorpe, 1997). Here, the individual evaluation of given alternatives is represented as a function of anticipated costs, benefits, and success probability. The process of educational attainment is conceptualised not only as a single decision but as a sequence of decisions that are observed as successive transitions across the educational career (Mare, 1980). In this respect, educational and occupational aspirations represent stages of a successive process of the formation, continuous adaptation, and realisation of individual goals (Schoon and Lyons-Amos, 2016). They continuously develop and when a decision situation - a so-called 'turning-point' (Hodkinson and Sparkes, 1997) approaches, individuals have to finally evaluate their educational and occupational ambitions to make the decision, which is (subjectively) associated with costs, benefits, and success probability in order to maximise their individual prospects.

We focus on the last year of general schooling when students have to decide whether they opt for vocational training and hereby obtain a specific vocational degree or whether they postpone the immediate occupational choice by aiming at further general schooling. At this point in the life course, a rational evaluation of chances and 
consequences can be expected to be particularly present. Students as well as individuals closely related to them (significant others) can be expected to evaluate as rationally as possible costs, benefits, and the probability of success for the subsequent educational or vocational stage. In this respect, the basic arguments of the rational-choice model fit well with the overall concept of the Wisconsin model; expectations of significant others are based on the rational assessment of the students' potential. In turn, students adapt these expectations by incorporating them into their own aspirations based on (rational) selfreflection (Morgan, 1998). Regarding regional conditions, it could be argued that high local unemployment or shortages in training opportunities should lead to a greater awareness of labour-market prospects by students and their significant others. Subsequently, given educational and occupational alternatives are more carefully assessed considering the regionally limited opportunities.

\section{Dimensions of educational and occupational aspirations}

We argue that the selection of relevant dimensions of aspirations is based on the specific stage and institutional prerequisites in the educational career (e.g. parents' vs. children's aspirations (Spera et al., 2009; Irwin and Elley, 2013), realistic vs. idealistic aspirations (e.g. Haller, 1968)). We provide an overview of general distinctions between aspirational dimensions in Figure 1. The most important ones for the purpose of our study are highlighted.1

Occupational aspirations typically refer to preferences towards anticipated aspects of a future occupation such as field and prestige of an occupation or normative roles for specific social groups (Gottfredson, 1981; Daymont and Andrisani, 1984; Osipow and Fitzgerald, 1996; Armstrong and Crombie, 2000). Following the theoretical outline, we suggest that structural aspects related to occupations become particularly relevant when focusing on a stage in an adolescent's educational career immediately before the choice on a specific occupation must be made.

\footnotetext{
${ }^{1}$ Note: illustrated in Figure 1 are several dimensions of educational and occupational aspirations that can become more or less relevant given the specific stage in the educational career. Moreover, they influence each other. Highlighted in bold black are dimensions that directly refer to this study.
} 


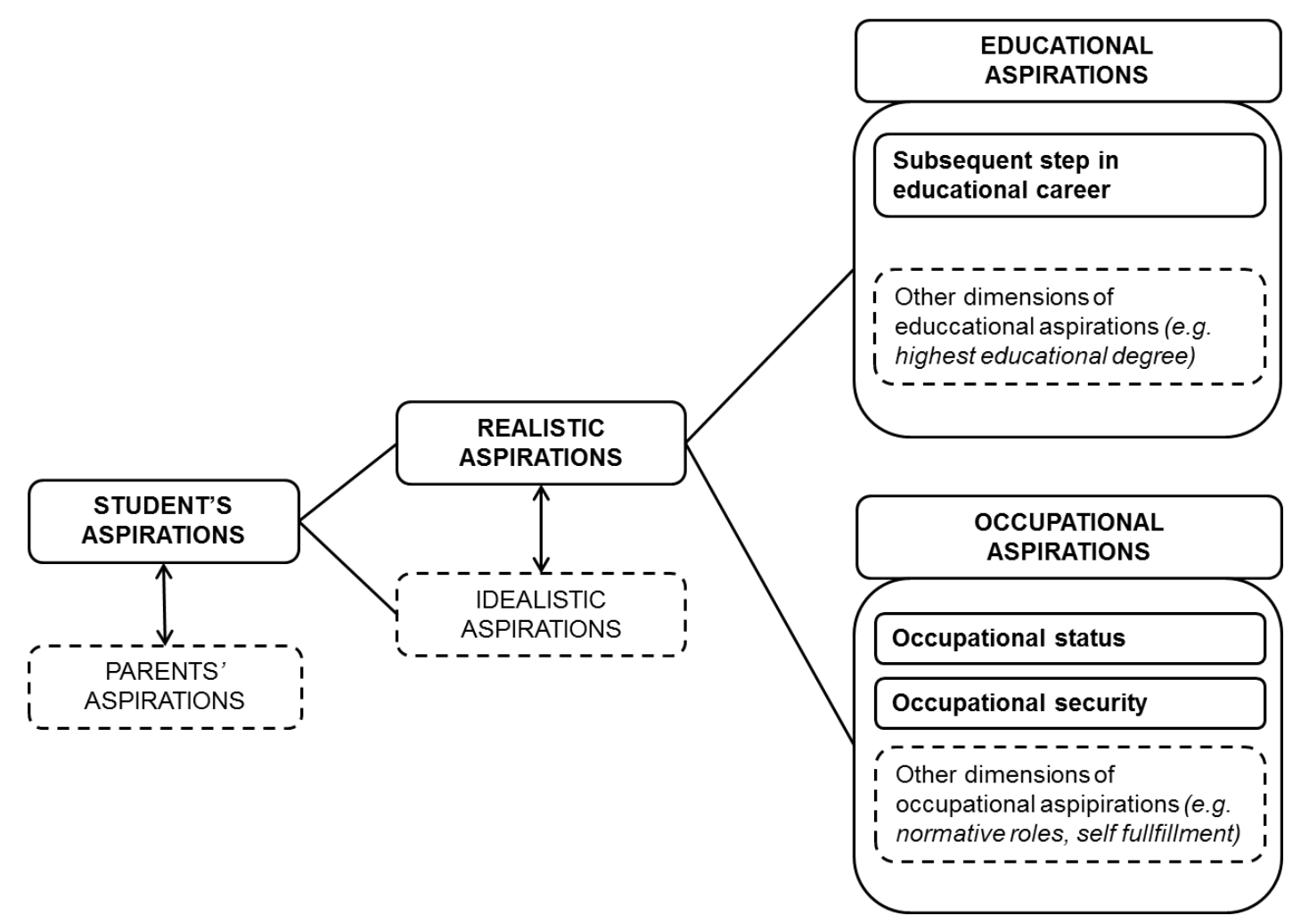

We differentiate between two structural components of aspirations: occupational security and occupational status. Both are important for individual training and labourmarket chances and are expected to be considered in students' rational evaluation of given opportunities. In terms of the relation between educational and occupational aspirations, we argue that a specific occupation usually requires a certain level of (general) education (e.g. a university degree is necessary to become a medical doctor). Assuming a rational actor, aspirations for a specific occupation should be reflected in the overall level of educational aspirations.

\section{5. (Post-)secondary schooling in Germany: Institutional preconditions}

To empirically illustrate our arguments, we choose the case of Germany. The stratified education system confronts students in lower and intermediate secondary tracks in their last year of general schooling with an active choice between the alternatives: staying on 
in general education versus pursuing VET. ${ }^{2}$ Due to the strongly developed German VET system and the close connection between VET and the labour market, regional labourmarket conditions are particularly relevant for the formation of occupational aspirations of students at this educational stage.

Figure 2. Basic structure of the German educational system with potential educational pathways (bold arrows) after lower and intermediate-secondary education (boxes with bold text frames). In parentheses: final grade of the school track

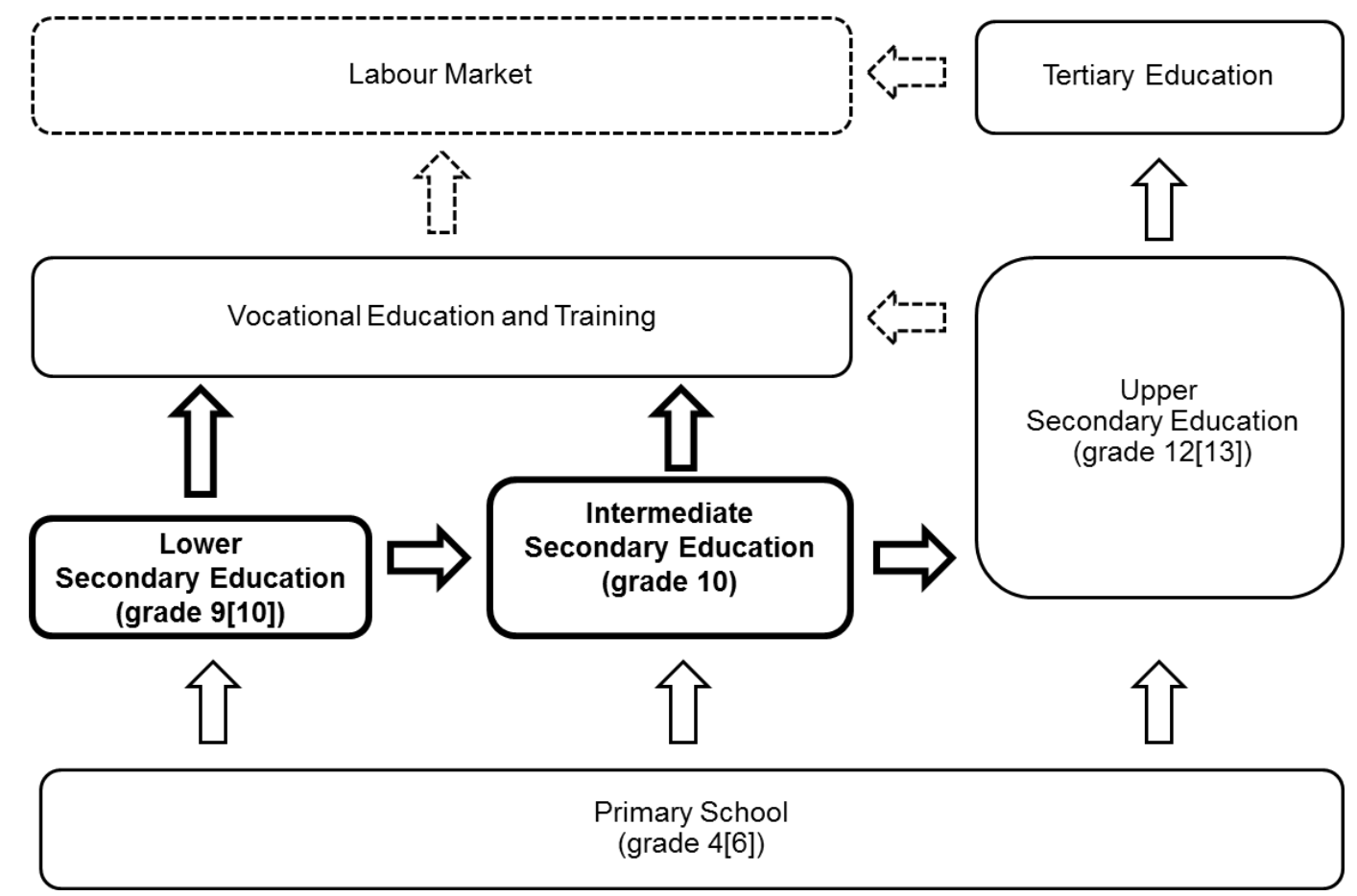

Early tracking in the German school system takes place after primary school (typically grade 4 or 6). Students are selected according to their performance into either lower-level (Hauptschule), intermediate-level (Realschule), or upper-level (Gymnasium) secondary school. This paper concentrates on students in lower and intermediate secondary school in their last compulsory year of schooling. At this stage, students are

\footnotetext{
${ }^{2}$ It is in principle possible to directly enter the workforce without vocational training. This is, however, not likely; the vast majority of graduates of lower or intermediate secondary school proceeds to VET. This is particularly the case if students are younger than 16 or 18 years (depending on the federal state) due to compulsory school regulations.
} 
aged 15 to 17 . Students in lower and intermediate secondary school finish general education at the latest after grade 10 and face the decision regarding their occupational career during their last year of schooling. Figure 2 demonstrates their possible choice: fields with bold frames indicate the educational tracks that we focus on in this paper; bold arrows illustrate the students' possible options after graduation.

The 'dual training' makes up the largest proportion of all VET positions. Dual training is characterised by on-the-job training that is provided by employers accompanied by course units in vocational schools. This feature of the German education system ensures, on the one hand, a smooth transition from training to employment; on the other hand, it makes the training system susceptible to (regional) economic variations. Since dual training is provided and financed by firms, the number of available vacancies is directly connected to the firms' economic situation. The average economic situation and subsequently the availability of education and training alternatives vary regionally. In the following section we will theoretically relate these regional variations to adolescents' aspirations for the given alternatives.

\section{Research hypotheses}

Young adults who graduate from lower and intermediate school tracks are typically between 15 and 17 years old at this point, and, although commuting is in principle possible, they are most likely bound to the regional area they currently live in. For this reason, we can expect them to be especially aware of and susceptible to the economic situation in the regional area when considering their vocational future. According to the rational choice model of educational decision-making, young people integrate the perceived structural constraints in their evaluation of potential benefits of given educational and occupational alternatives. The overall assumption is that individuals associate poor labour-market conditions with an increased individual risk of becoming unemployed in the future. This leads to two potential strategies school graduates may use to respond to this risk:

On the one hand, poor labour-market conditions can motivate individuals to aspire those occupations that promise the highest employment chances regardless of their status. High job stability ensures a low risk of becoming unemployed and secures a stable income 
over the life course. On the other hand, individuals may strive for high-status occupations associated with a higher income. Even if individuals who aim at high-status occupations might risk phases of (temporary) unemployment, it can be assumed that phases of unemployment are compensated by an overall greater monthly income and hence higher expected monetary benefits across the life course.

H1.1 (Security-aspiration hypothesis): The higher the level of regional unemployment is, the higher are the realistic aspirations for more secure occupations.

H1.2 (Status-aspiration hypothesis): The higher the level of regional unemployment is, the higher are the realistic aspirations for occupations with a higher status.

The impact of contextual conditions on status- and security-related aspects of occupational aspirations can be expected to manifest itself in the actual intention of school graduates to remain in general schooling or to leave it. If the students strive for highstatus occupations and more secure jobs, they will subsequently intend to extend their general school career in order to attain the required level of overall qualification. In addition, students who anticipate a poor regional labour-market situation can be expected to be aware of the lower supply with vocational training places. Participation in general education postpones the transition to training and employment and opens up the possibility to enrol in higher education. Therefore, this should reduce the risk of inactivity or unemployment.

H1.3 (Educational-aspiration hypothesis): The higher the level of regional unemployment is, the higher are the realistic aspirations to continue general schooling after graduation from lower or intermediate secondary school.

The institutional features of the German education system are taken into account by considering that students in lower-level secondary schools might be differently affected by the regional situation than students in intermediate secondary schools. Employers tend to prefer graduates with a higher school qualification (Spence, 1973; 
Thurow, 1975). This is particularly the case when training places are limited. Students in lower-secondary schools might anticipate their competitive disadvantage and, therefore, tend to be more sensitive to regional labour-market conditions.

H2 (Qualification-specific hypothesis): Associations between the level of regional unemployment and all three dimensions of aspirations are stronger for lower-secondary school graduates compared to intermediate-level secondary school graduates.

Furthermore, we consider the socialisation environment in which individuals are embedded. In accordance with the Wisconsin model of social status attainment, we expect students' educational and occupational aspirations and their sensitivity to external factors to be interrelated with aspirations of the significant others, in particular of family members. Idealistic aspirations of the parents serve as an indicator of the predominant normative attitudes towards education within the family. Students confronted with high familial expectations can be expected to be less sensitive to variation in macro-level economic conditions.

H3 (Familial-norm hypothesis): Associations between the level of regional unemployment and the three dimensions of aspirations are weaker if idealistic educational aspirations are high within the family.

\section{Data and analytical strategy}

To test the five outlined hypotheses, we make use of data from the National Educational Panel Study - Starting Cohort 4 -9th Grade (NEPS-SC4, v.4.0.0). ${ }^{3}$ The NEPS-SC4 is a survey that initially targeted $9^{\text {th }}$ graders in lower, intermediate, and upper-level secondary schools in Germany. We are interested in students from lower and intermediate tracks and their occupational and educational aspirations shortly before their graduation. For

\footnotetext{
3 This paper uses data from the National Educational Panel Study (NEPS): Starting Cohort 4 - 9th Grade, doi:10.5157/NEPS:SC4:4.0.0. From 2008 to 2013, NEPS data was collected as part of the Framework Program for the Promotion of Empirical Educational Research funded by the German Federal Ministry of Education and Research (BMBF). Since 2014, NEPS has been carried out by the Leibniz Institute for Educational Trajectories (LIfBi) at the University of Bamberg in cooperation with a nationwide network (Blossfeld et al., 2011; Skopek et al., 2013).
} 
this reason, we identify the wave of the last regular year in their initial school. As students in lower-secondary school in parts graduate after grade 9 and in parts after grade 10, we accordingly considered information from the wave one (autumn 2010) and the wave three (autumn 2011). As students in intermediate secondary school graduate after grade 10, in this case we consider the information from autumn 2011. Students who attend upper-level secondary school (Gymnasium) are excluded as they do not necessarily face the decision of staying in school versus entering vocational training. They can actively decide to leave school but in the vast majority of cases they continue the standard pathway of general schooling until grade 12 or 13 . Our respondents are aged 15 to 17 . We define our three dependent variables as follows:

Security-related occupational aspirations: In NEPS-SC4, students have been asked to report the occupation they realistically expect to work in in the future. Reported occupational titles are provided in the data in different coding systems. The NEPS data on the aspired occupation is matched to occupation-specific unemployment rates in order to develop a structural construct that represents the employment security of specific occupations. Occupation-specific unemployment rates are measured by using the Klassifikation der Berufe (KldB) 1988, a standard classification of the German Federal Labour Office, which is based on a distinction of up to 99 major occupational groups. The Federal Labour Office provides the number of current positions in each occupation and the number of unemployed persons assigned to each occupational group on a monthly basis. By connecting these occupation-specific unemployment rates (taken from July of the previous year) with the reported aspired occupations, we generate an indicator of the unemployment risk in the preferred occupation. The higher the occupation-specific unemployment rate in the aspired occupation, the more insecure we consider this aspired occupation to be.

Status-related occupational aspirations: To measure the status of the aspired occupation, we use the International Socio-Economic Index of Occupational Status (ISEI) 2008. ISEI is a standard classification which is based on a distinction of up to 390 unique occupational groups. The ISEI variable is a metric representation of the status of an occupation based on the required level of education and income expectations, with a minimum value of 16 and a maximum value of 90 (Ganzeboom and Treiman, 1996). The 
occupation that respondents prefer was coded accordingly to represent status-related occupational aspirations.

Compared to a subjective report of the individual importance of future job status and security, these structural measures have the advantage that they make differences in preferences observable even when the students are not explicitly aware of it. We decided to integrate the overall unemployment rate and not youth unemployment for three reasons. First, both unemployment indicators are highly correlated on the regional level. Second, the overall unemployment rate is much more visible (e.g. reported in local news) than the youth unemployment rate. This is important since we are interested in aspirations, the focus is on the perception of opportunities rather than on the actual availability of opportunities. Third, we additionally incorporate the availability of training places to capture the chance to enter vocational training in the region.

Education-related aspirations: The third dependent variable is the realistic aspiration to continue further general schooling. This information is based on the question of what the respondent realistically intends to do one year after the interview takes place. It is coded as a binary variable that captures the intention to continue versus to leave general school.

We use information on the respondents' place of residence to link survey information with regional indicators from administrative sources (see also Hillmert et al., 2017a). According to previous research, NUTS-3 units (administrative districts) ${ }^{4}$ and the adjacent neighbouring NUTS-3 areas represent the most adequate operationalisation of the regional areas that are relevant for school-to-training transitions (Weßling et al., 2015). We therefore make use of this conceptualisation of training areas. In our sample the respondents are distributed among 300 districts.

To operationalise our explanatory variable, we use the unemployment rate in the regional area in which adolescents live during their last year of schooling. Unemployment rates are captured for the years 2000 to 2010. Unemployment data is used in time-series format in order to make it possible to decompose regional from temporal trends in unemployment. This allows for capturing the regional labour-market conditions as specifically as possible. For a detailed description of the decomposition approach, see

\footnotetext{
${ }^{4}$ The NUTS (Nomenclature des unités territoriales statistiques) represents a geocoded standard to reference regional units in the European Union. NUTS 3 refer to areas with approximately 150,000 to 800,000 inhabitants and resemble the German classification of 'Kreisfreie Städte' und 'Landkreise'.
} 
Hillmert et al. (2017b). In doing so, the explanatory variable represents a region's level of unemployment relative to the overall unemployment. Because regional trends can be smaller than the overall trend, the relative regional unemployment variable can have negative values.

The attended school track is represented by a binary variable indicating that lower secondary school and not intermediate secondary school is attended. Attitudes towards education within the family are captured by parents' idealistic aspirations for their children to obtain higher education in the future. Moreover, several control variables on the individual level are included; because parents' aspirations are strongly correlated with their level of education (Spera et al., 2009), potential confounding effects of social background are captured via parents' educational status.

We expect school grades to be the most visible information that individuals use to assess their own ability. This assessment can again affect their educational aspirations. Therefore, grades in Mathematics and German are included. For a more intuitive interpretation of the models, reported grades are reversed so that they range between 1 (worst) and 6 (best). Further controls are sex and migration background because these characteristics are known to be associated with occupational and educational aspirations (Mau and Bikos, 2000). 


\begin{tabular}{|c|c|c|c|c|}
\hline Parameter & $\mathrm{M} /$ Pct. & SD & Min & Max \\
\hline \multicolumn{5}{|l|}{ Dependent variables: individual level } \\
\hline \multicolumn{5}{|l|}{ 1) Security-related occupational aspirations: } \\
\hline Unemployment rate in aspired occupation (\%) & 7.40 & 5.1 & 0.1 & 29.1 \\
\hline \multicolumn{5}{|l|}{ 2) Status-related occupational aspirations: } \\
\hline ISEI of the aspired occupation & 45.8 & 18.0 & 11.6 & 88.7 \\
\hline \multicolumn{5}{|l|}{ 3) Education-related aspirations: } \\
\hline \multicolumn{5}{|l|}{ Aspirations to continue schooling: } \\
\hline Yes & $39.4 \%$ & & & \\
\hline No & $60.6 \%$ & & & \\
\hline \multicolumn{5}{|l|}{ Contextual level } \\
\hline Level of regional unemployment ${ }^{1}$ (in $\%$ points) & -1.2 & 2.8 & -5.6 & -7.7 \\
\hline \multicolumn{5}{|l|}{ Individual level } \\
\hline \multicolumn{5}{|l|}{ School track: } \\
\hline Lower secondary & $41.1 \%$ & & & \\
\hline Intermediate secondary & $58.9 \%$ & & & \\
\hline Performance in German & 4.1 & 0.8 & 1 & 6 \\
\hline Performance in Maths & 4.0 & 1.0 & 1 & 6 \\
\hline \multicolumn{5}{|l|}{ Parents' aspirations for higher education: } \\
\hline Yes & $21.3 \%$ & & & \\
\hline No & $78.7 \%$ & & & \\
\hline \multicolumn{5}{|l|}{ Parents- at least one has Abitur: } \\
\hline Yes & $35.5 \%$ & & & \\
\hline No & $64.5 \%$ & & & \\
\hline \multicolumn{5}{|l|}{ Sex: } \\
\hline Male & $54.8 \%$ & & & \\
\hline Female & $45.2 \%$ & & & \\
\hline \multicolumn{5}{|l|}{ Migration background: } \\
\hline Yes & $17.9 \%$ & & & \\
\hline No & $82.1 \%$ & & & \\
\hline
\end{tabular}

Note. $\mathrm{N}$ individuals $=1,629 ; \mathrm{N}$ regions $=300 ;{ }^{1}$ linear trend of regional unemployment rate - linear trend of national unemployment rate; source: NEPS-SC4, Federal Employment Office / BBSR, own calculation

We apply linear regression techniques (OLS) for the analyses of occupational aspirations. Since the outcome of the third dependent variable (the aspirations to continue general schooling) is binary, we apply a linear probability model (LPM). The LPM uses a multiple linear regression to explain qualitative events using a binary dependent variable. The coefficients of such a linear model can be interpreted as the change in the probability of a defined event given a one-unit change in the independent variable, holding covariates fixed (Wooldridge, 2006). The assumption of homoscedasticity will necessarily be violated. To ensure the validity of the statistical tests, we calculate 
heteroscedasticity-robust standard errors (White, 1980). The NEPS-SC4 sample is clustered within schools; in our sample, individuals are distributed among 327 schools. To account for the clustered sampling design, we apply a multilevel model with schools as level-two units. To estimate the explanatory power of the models, we present a null model illustrating the initial distribution of residual variance terms of the dependent variables. In a second step, the regional unemployment and the variables on the individual level are included. Interaction terms are integrated in the third model (see Table 2).

\section{Empirical results}

The empirical results are presented in Table 2 to 4 with separate tables for each of the three dependent variables; security-related occupational aspirations (Table 2); statusrelated occupational aspirations (Table 3) and general educational aspirations (Table 4). In hypothesis 1.1., we expected the level of regional unemployment to be associated with aspirations for more secure occupations. This should be indicated by a negative coefficient with occupation-specific unemployment risk as the dependent variable.

The comparison between the null model and the model including control variables on the individual level (see Table 2, Model 1 and Model 2) shows a 1\% reduction in the residual variance, $\left(100-24.379 / 24.665^{*} 100\right)$, indicating a very weak explanatory power of the individual-level variables. Model 2 shows a positive effect for students in lowersecondary schools. This means that their expectations for obtaining secure jobs are lower compared with intermediate-secondary school students.

Neither parents' educational status nor their aspirations show significant effects. Regional-level indicators are introduced in Model 3 and corresponding interaction terms are introduced in Model 4. None of the expected associations with security-specific aspirations is significant. The analyses show that security-related aspirations seem not to be subject to regional labour-market conditions in any respect. Thus, our hypothesis on the relevance of the security in aspired occupations cannot be confirmed. 
Table 2. Linear regression model, dependent variable: unemployment rate in the aspired occupation

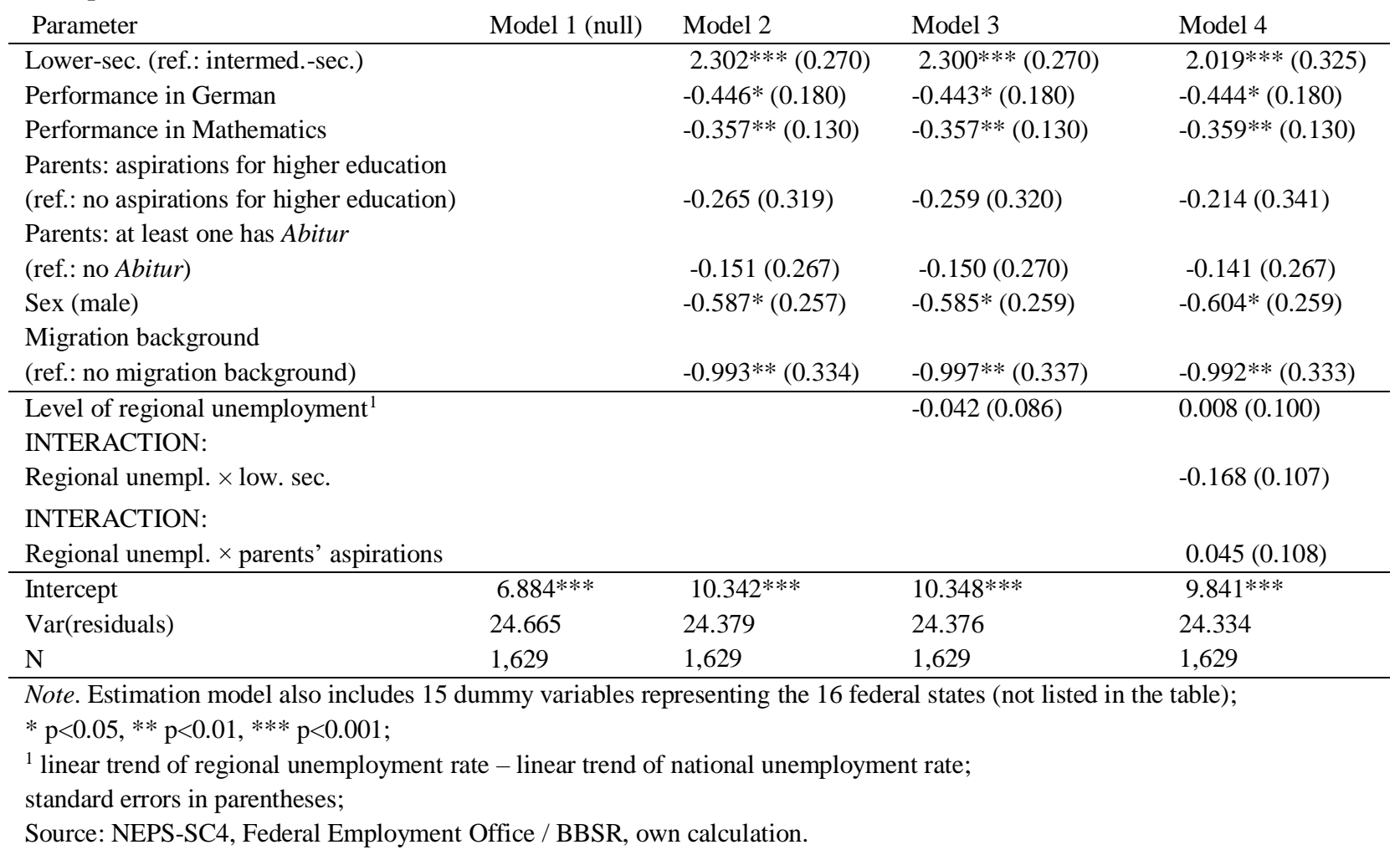

In a second step, we focus on status-related aspirations. ${ }^{5}$ We expect the level of regional unemployment to be (positively) associated with aspirations for occupations with higher status indicated by a positive effect on status aspirations in the model. For the results see Table 3. The comparison between the null model and the model with individual-level control variables (see Table 3, Model 1 and Model 2) shows that the individual level explains more than $19 \%$ of the variation in status aspirations. In substantive terms we find that students in lower-secondary school have lower job-status aspirations compared to students in intermediate-secondary school.

\footnotetext{
${ }^{5}$ As there is a correlation between both constructs of occupational aspirations (-0.3), we performed alternative analyses within an SEM-framework that explicitly accounted for the correlation between dependent variables. As the results remained stable, only the separate models, which are easier to read, are presented here.
} 
Table 3. Linear regression model, dependent variable: ISEI of the aspired occupation

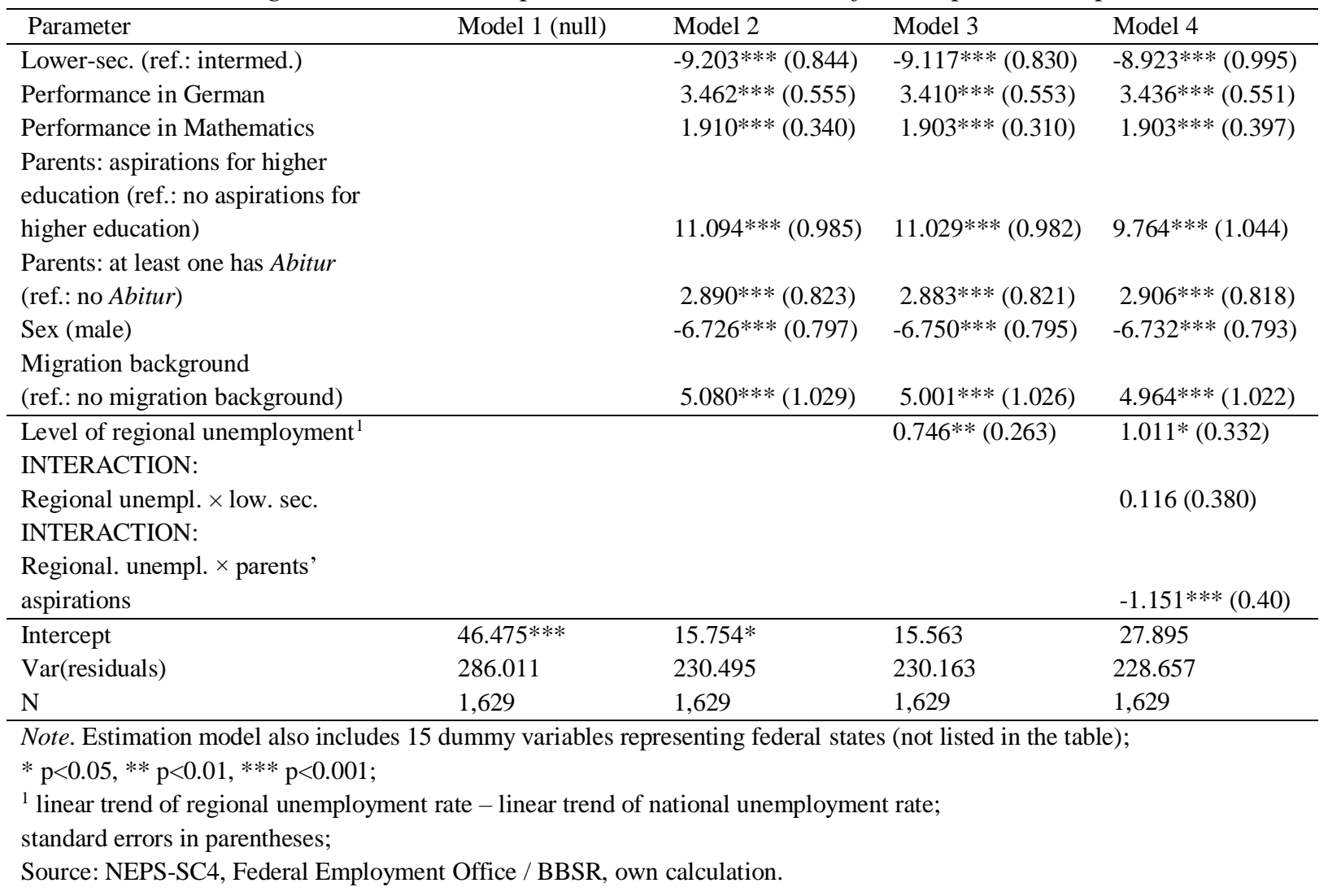

This is reasonable given their lower level of qualification. In contrast to the model on security-related occupational aspirations (Table 2), we find that the social background of students has an influence; parents' educational status has a positive but rather weak effect. However, if parents' idealistic aspirations for their child are high, their child's expected occupational status increases by more than ten ISEI $^{6}$ points.

Regional-level indicators are introduced in Model 3, and the corresponding interaction terms are included in Model 4. The main effect of regional unemployment on status-related occupational aspirations in Model 3 is positive and significant, indicating that tense regional labour-market conditions foster status-related aspirations. The interaction term between parents' aspirations and the regional unemployment in Model 4 demonstrates that the regional unemployment does not play a role for status aspirations if parental educational aspirations are high. In other words, tense regional labour-market conditions neutralise the positive association between parent's idealistic educational aspirations for their children and their realistic occupational aspirations. The non-

\footnotetext{
${ }^{6}$ Note that the ISEI-08 scale ranges from 11.56 to 88.96 .
} 
significant interaction term between regional unemployment and the school track indicates that regional conditions are similarly relevant for status related occupational aspirations of lower- and intermediate-secondary school students. This does not confirm our hypothesis because we argued that lower-secondary track students should be affected more strongly.

As a consequence of striving for higher status and security occupations in more deprived regions, we expect aspirations for further general schooling to also be higher in more deprived regions. The corresponding results are depicted in Table 4. The parental educational aspirations have a strong and significant effect on aspirations to further attend general school. This is in line with the overall argument of the Wisconsin model of status attainment, stating the strong influence of significant others, especially within the family. In contrast to our expectations we find no independent influence of the attended school track. However, the effect becomes negative and significant when introducing an interaction terms between school track and regional unemployment in the Model 4.

We find a higher level of regional unemployment to be associated with a significant increase of students' aspirations to continue general education (see Table 4, Model 3). Introduced interaction terms between regional unemployment and school track as well as parents' aspirations point in the expected direction but are not significant. Thus, regional unemployment conditions do not attenuate the association between the attended school track and occupational and educational aspirations. 
Table 4. Linear probability model (LPM), dependent variable: aspirations for further education (1) vs. no aspirations for further general education (0)

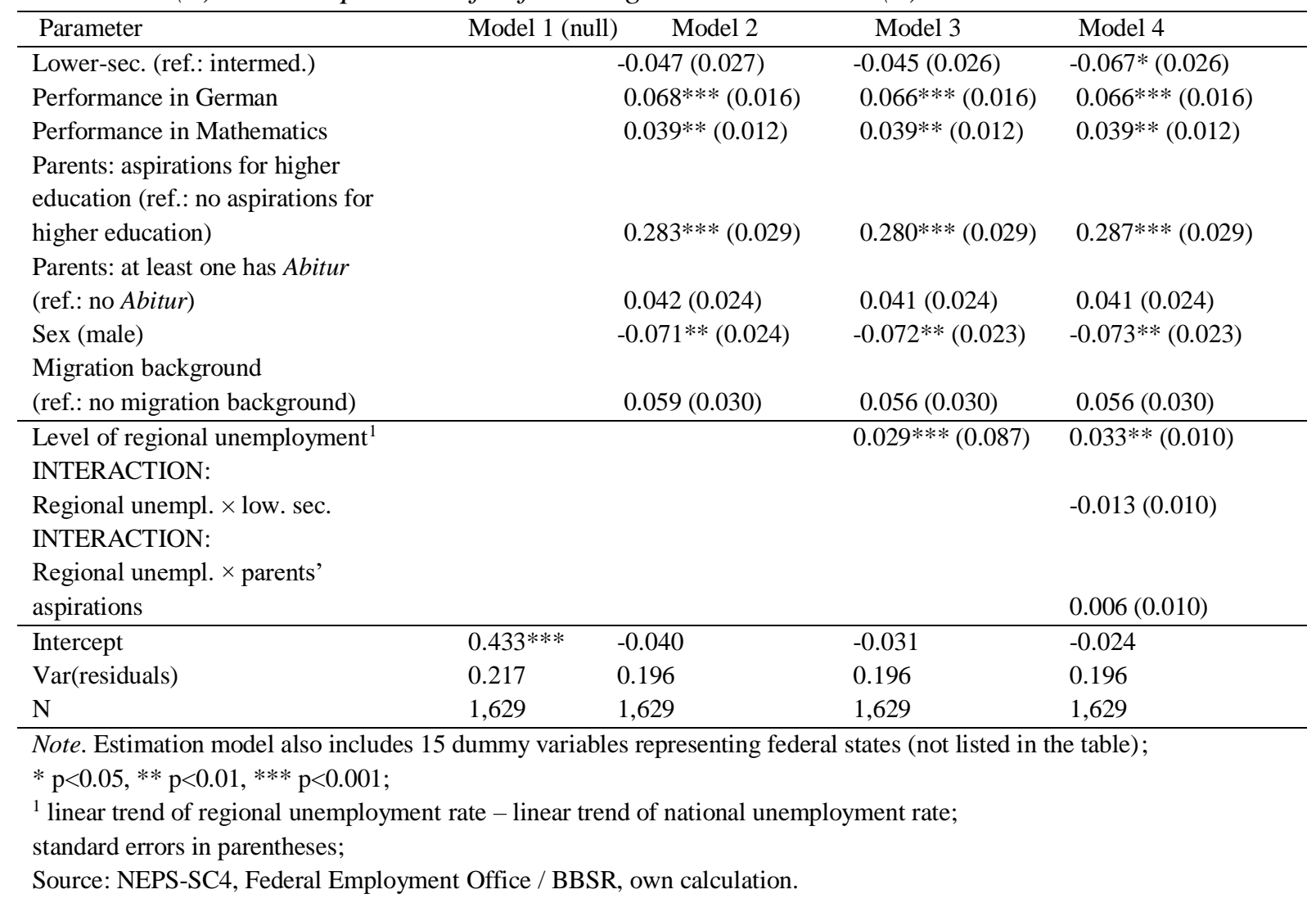

Compared to the individual-level characteristics, the introduction of regional indicators and interactions terms leads to a relatively small improvement of the overall explanatory power of the models for three dependent variables (reduction error variance, Tables 2-4). Hence, it can be concluded that regional conditions are of importance for educational and occupational aspirations, but their relevance is subordinate given the role of well-known and well-studied individual explanatory factors like school performance, social, and ethnic background or gender. However, we find it is important to consider the regional context in terms of interaction effects. They indicate that different groups of individuals respond very differently to the same regional conditions. In particular the moderating relation between parental aspirations for their children and the regional economic conditions appears to be relevant in explaining occupational aspirations. 


\section{Summary and discussion}

The focus of this paper has been on dimensions of occupational and educational aspirations of students at the end of (lower and intermediate) secondary school and on the association between aspirations and regional labour-market conditions.

Our aim has been, to propose an approach that includes educational and occupational goals simultaneously and relates them to a specific stage in adolescents' educational careers. We have applied this concept to assess the influence of the regional situation on students' occupational and educational aspirations. Regional labour-market conditions were expected to be of importance for realistic aspirations shortly before the end of compulsory schooling because at this stage in the educational career young adults have to seriously evaluate their wishes and chances against the background of given opportunities in an accessible residential area.

On the regional level, we used unemployment data on administrative districts and aggregated them to the level of training areas. On the individual level, data from NEPSSC4 has been used. Our findings can be summarised as follows: status-related occupational aspirations as well as aspirations to attend further general education are significantly associated with regional labour-market conditions. Whereas security-related aspirations are not significantly affected by regional labour-market conditions.

In terms of effect heterogeneities, we find that students occupational status aspirations in lower versus in intermediate school tracks are not differently affected by regional labour-market conditions. However, we do find differences in regional effects with regard to the parental educational aspirations. Students that are confronted with high idealistic educational aspirations of their parents are much less sensitive to economic conditions in the region and generally more likely to aspire high-status occupations, whereas lower parental aspirations strongly increase the positive effect of regional unemployment on the likelihood to aspire high-status occupations. We do not find significant interaction effects on security-related occupational aspirations. Thus, it seems that - compared with status - security is a less important dimension for young adults' occupational aspirations at this stage of their occupational career. However, an additional explanation may refer to the extent to which young adults are informed about job characteristics. School students do not - or only to a limited extent - gather and obtain information on sector-specific unemployment rates in their region. Expectations about 
occupational security may be shaped less by actual conditions in a specific occupation than by significant others such as family, peers, neighbours, and teachers. We can assume that the perception of what is referred to as a secure job can be much different from the actual regional unemployment risk in an occupation. Moreover, although we find the unemployment rate in the aspired aspirations to vary between 0 and 29\% (see Table 1), it could be, also given the number of cases available in the NEPS-SC4 that these variations in occupation-related unemployment rates are simply too small to find a relation. Results that refer to the status of an occupation are more reliable because the perception of job status is probably closer to common knowledge. We find a clear link between regional labour-market conditions and the aspirations to stay on in general school; the poorer the regional economic conditions the more likely it is to strive for a higher level of general education. But in contrast to our expectations, the effect of regional unemployment does not vary with the school track or with parental aspirations.

We have to limit the scope of our findings due to the fact that NEPS-SC4 data does not contain information on young people's aspirations in the years before grade 9 . We are not able to make a statement on the development of educational aspirations prior to the last year of schooling. We assume that at the observed stage of the education career, students are more rational and, thus, more strongly affected by regional labour-market conditions. However, longitudinal data would be necessary to test this assumption.

In terms of avenues for further research, we know that the labour market integration of school leavers differs considerably across countries (Wolbers, 2007; Levels et al., 2014). Hence, a comparison of effects of regional labour-market conditions on the formation of adolescents' aspirations given country-specific institutional settings seems fruitful to further elaborate on the presented approach. Germany provides an interesting case with the VET system being closely linked to the regional labour market. Our analytical strategy could be adapted for countries in which VET systems are less dependent on the labour-market situations such as countries with predominantly schoolbased vocational training (e.g. Sweden). Here, weaker associations between regional labour-market conditions and occupational aspirations can be expected. The presented approach is also promising in exploring the relation between regional labour-market conditions and individual aspirations in countries with no strongly developed VET system, where students can transfer directly from general schooling to employment (e.g. 
UK). In these countries, aspirations for tertiary education might represent a strong alternative to the labour-market entry in a regional situation perceived as poor, and also the immediate unemployment risk can be expected to be higher. In this case the associations between aspirations and the labour market could be expected to be even stronger compared to the presented application.

Overall, the relation between regional characteristics and aspirations has so far received little attention in empirical research, and although our findings suggest that regional labour-market conditions are generally of comparatively little importance, it is a particularly relevant finding in terms of social inequality that lower-secondary school students and students with lower familial preferences for higher education are to a notably extent affected by the regional economic situation.

From the perspective of policy makers and education providers, our findings indicate the importance of additional support for students who are considered to have low chances on the training and labour market, especially in regional contexts with a disadvantageous socio-economic situation. Meaningful information about training occupations and educational pathways are most important when opportunities are limited. The better informed young graduates are about their occupational choices and the greater their awareness for particular opportunities is, the less unintended consequences such as detours and setbacks in their educational and occupational careers can be expected.

\section{References}

Anders L, Anisef P, Krahn H, Looker D and Thiessen V (1999) The Persistence of social structure: Cohort, class and gender effects on the occupational aspirations and expectations of Canadian youth. Journal of Youth Studies 2(3): 261-282.

Armstrong PI and Crombie G (2000) Compromises in adolescents' occupational aspirations, and expectations from grades 8 to 10. Journal of Vocational Behavior 56(1): 82-98.

Beal SJ and Crockett LJ (2010) Adolescents' occupational and educational aspirations and expectations: Links to high school activities and adult educational attainment. Developmental Psychology 46(1): 258-265.

Betts JR and McFarland LL (1995) Safe port in a storm: The impact of labour market conditions on community college enrolments. Journal of Human Resources 30(4): 741-765.

Blossfeld H-P, Roßbach H-G and von Maurice J (eds) (2011) Education as a lifelong process: The German National Educational Panel Study NEPS. Zeitschrift für Erziehungswissenschaft 14, special issue. 
Boudon R (1974) Education, opportunity, and social inequality: Changing prospects in western society. New York: Wiley.

Breen R and Goldthorpe JH (1997) Explaining educational differentials: Towards a formal rational action theory. Rationality and Society 9(3): 275-305.

Carmeci G and Chies L (2002) Education and local labour market: The case of Italy. Lavoro e Relazioni Industriali 1: 55-93.

Chesters J and Smith J (2015) Social capital and aspirations for educational attainment: A cross-national comparison of Australia and Germany. Journal of Youth Studies 18(7): 932-949.

Clark D (2011) Do recessions keep students in school? The impact of youth unemployment on enrolment in post-compulsory education in England. Economica 78(311): 523-545.

Daymont TN and Andrisani PJ (1984) Job preferences, college major, and the gender gap in earnings. Journal of Human Resources 19(3): 408-428.

Erikson R and Jonsson JO (1996) Can education be equalized? The Swedish case in comparative perspective. Boulder: Westview Press.

Frostick C, Phillips G, Renton A and Moore D (2016) The Educational and employment aspirations of adolescents from areas of high deprivation in London. Journal of Youth and Adolescence 45(6): 1126-1140.

Ganzeboom HBG and Treiman DJ (1996) Internationally comparable measures of occupational status for the 1988 International Standard Classification of Occupations. Social Science Research 25(3): 201239.

Gesthuizen M and Scheepers P (2010) Economic vulnerability among low-educated Europeans. Acta Sociologica 53(3): 247-267.

Gottfredson LS (1981) Circumscription and compromise: A developmental theory of occupational aspirations. Journal of Counseling Psychology 28(6): 545-579.

Gutman LM and Schoon I (2017) Aiming high, aiming low, not knowing where to go: Career aspirations and later outcomes of adolescents with special educational needs. International Journal of Educational Research. Online first

Haller AO (1968) On the concept of aspiration. Rural Sociology 33(4): 484-487.

Haller AO (1982) Reflections on the social psychology of status attainment. In: Hauser RM, Mechanic D, Haller AO and Hauser TS (eds) Social structure and behavior: Essays in honor of Willy Hamilton Sewell. New York, London, Paris: Academic press, pp. 3-28.

Hartung A and Hillmert S (2019) Assessing the spatial scale of context effects: The example of neighbourhoods' educational composition and its relevance for individual aspirations. Social Sciences Research. Online first: https://doi.org/10.1016/j.ssresearch.2019.05.00.

Hillmert S, Hartung A and Weßling K (2017a) Dealing with space and place in standard survey data. Survey Research Methods 11(3): 267-287. DOI:10.18148/srm/2017.v11i3.6729

Hillmert S, Hartung A and Weßling K (2017b) A Decomposition of local labour-market conditions and their relevance for inequalities in transitions to vocational training. European Sociological Review 33(4): 534-550. 
Hodkinson P and Sparkes AC (1997) Careership: A sociological theory of career decision-making. British Journal of Sociology of Education 18(1): 29-44.

Holtmann AC, Menze L and Solga H (2017) Persistent disadvantages or new opportunities? The role of agency and structural constraints for low-achieving adolescents' school-to-work transitions. Journal of Youth and Adolescence 46(10): 2091-2113.

Irwin S and Elley S (2013) Parents' hopes and expectations for their children's future occupations. The Sociological Review 61(1): 111-130.

Kleinert C and Jacob M (2012) Strukturwandel des Übergangs in eine berufliche Ausbildung. In: Becker R and Solga H (eds) Soziologische Bildungsforschung. Wiesbaden: Springer, pp. 211-234.

Levels M, van der Velden R and Di Stasio V (2014) From school to fitting work. Acta Sociologica 57(4): 341-361.

Listhaug O, Ringdal K and Ingebrigtsen O (1982) Status attainment in urban and rural labour markets. Acta Sociologica 25(3): 269-282.

Mare R (1980) Social background and school continuation decisions. Journal of the American Statistical Association 75: 293-305.

Mau W and Bikos LH (2000) Educational and vocational aspirations of minority and female students: A longitudinal study. Journal of Counseling and Development 78: 66-74.

Meschi E, Swaffield J and Vignoles A (2011) The relative importance of local labour market conditions, and pupil attainment on post-compulsory schooling decisions. IZA Discussion Paper No. 6143.

Minello A and Barban N (2012) The educational expectations of children of immigrants in Italy. The Annals of the American Academy of Political and Social Science 643(1): 78-103.

Morgan SL (1998) Adolescent educational expectations: Rationalized, fantasized, or both? Rationality and Society 10(2): 131-162.

Osipow SH and Fitzgerald LF (1996) Theories of career development. Boston: Allyn and Bacon.

Peraita C and Pastor M (2000) The primary school dropout in Spain: The influence of family background and labour market conditions. Education Economics 8(2): 157-168.

Raffe D and Willms DJ (1989) Schooling the discouraged worker: Local-labour-market effects on educational participation. Sociology 23(4): 559-581.

Rice P (1999) The impact of local labour markets on investment in further education: Evidence from the England and Wales youth cohort studies. Journal of Population Economic 12(2): 287-312.

Schoon I, Martin P and Ross A (2007) Career transitions in times of social change: His and her story. Journal of Vocational Behavior 70(1): 78-96.

Schoon I and Lyons-Amos M (2016) Diverse pathways in becoming an adult: The role of structure, agency and context. Research in Social Stratification and Mobility 46: 11-20.

Sewell WH, Haller AO and Portes A (1969) The educational and early occupational attainment process. American Sociological Review 34(1): 82-92.

Skopek J, Pink S and Bela D (2013) Starting cohort 4: $9^{\text {th }}$ grade SC4. SUF version 1.1.0. Data manual, NEPS research data paper. Bamberg.

Spence, M (1973) Job Market Signaling. The Quarterly Journal of Economics 87(3): 355-374 
Spera C, Wentzel KR and Matto HC (2009) Parental aspirations for their children's educational attainment: Relations to ethnicity, parental education, children's academic performance, and parental perceptions of school climate. Journal of Youth and Adolescence 38(8): 1140-1152.

Thurow L (1975) Generating Inequality. Basic Books: New York.

Walters PB (1984) Occupational and labour market effects on secondary and postsecondary educational expansion in the United States 1922 to 1979. American Sociological Review 49(5): 659-671.

Weßling K, Hartung, A and Hillmert S (2015). Spatial structure counts: The relevance of regional labourmarket conditions for educational transitions to vocational training. Empirical Research in Vocational Education and Training 7(12)

White H (1980) A heteroscedasticity-consistent covariance matrix estimator and a direct test for heteroscedasticity. Econometrica 48(4): 817-838.

Wicht A and Ludwig-Mayerhofer W (2014) The impact of neighbourhood s and schools on young people's occupational aspirations. Journal of Vocational Behavior 85(3): 298-308.

Wolbers MHJ (2007) Patterns of labour market entry. Acta Sociologica 50(3): 189-210.

Wooldridge JM (2006) Introductory econometrics: A modern approach, $2^{\text {nd }}$ ed. Mason: South-Western. 